\title{
Requirement Analysis and Design of RFID and Mobile Application based Attendance Management System: A Case Study of Ordinary Level Schools
}

\author{
Joseph Sospeter \\ School of Computational and Communication \\ Science and Engineering \\ Nelson Mandela African Institution of Science and \\ Technology \\ P.O Box 447, Arusha, Tanzania
}

\author{
Shubi Kaijage \\ School of Computational and Communication \\ Science and Engineering \\ Nelson Mandela African Institution of Science and \\ Technology \\ P.O Box 447, Arusha, Tanzania
}

\begin{abstract}
Mobile phone technology has continued to grow in terms of computation power, memory sizes and efficiency power utilization. The emergency of Smartphone has facilitated many applications for different activities to be developed. Smartphone are mobile phone with an advanced operating system and capable of running third-party applications [1]. Industry analysts estimate that there are more than 250,000 applications available through the various stores and marketplaces, some of which are available for multiple types of device[2].This paper presents requirement specifications and system design for RFID and mobile application based attendance management that can be useful in our ordinary schools and hence substitute the manual method of Attendance management which is tedious and error prone.
\end{abstract}

\section{Keywords}

Android, Mobile Application, Attendance Management, Use cases, UML, Requirement specifications, RFID

\section{INTRODUCTION}

Before implementation of any engineering project, it is a good practice to collect and analyse the requirement and produce a blue print design of the system. In software development, System requirements are the statements of what the system must do for its user in normal condition. They are categorized into functional and non-functional requirement. System requirement gathering and design are the early stages in software/system development life cycle (SDLC).

A mobile application is a computer program designed to run on Smartphone, tablet computers and other mobile devices[5] This paper presents functional and non-functional system requirements as well as design for developing an RFID and Mobile application based attendance management. Requirement specification for an information system is important for several reasons: it serves as a means of communication between the user and system developer; as a result, the right system will be developed. It also represents in a systematic fashion the current state of the real world, its problems and future requirements. Additionally, it enables the system developer to turn real world problems into other forms which are more manageable in terms of size, complexity, human understanding and computer process ability. Lastly, it serves as the basis for the design, implementation, testing and maintenance of the target system [6].

\section{MOBILE PHONE OPERATING SYSTEMS}

The most common operating systems used in smart mobile devices include the operating system Android (Google), iOS (Apple), Symbian (Nokia), BlackBerry OS (RIM), Samsung Bada, Microsoft Windows Phone, webOS (Hewlett-Packard) and Linux Maemo and MeeGo [8]. Operating systems that monopolize the mobile market are Android (by Google) with a share of $69.6 \%$ of installations and iOS (by Apple) with $20.9 \%$. The shares for the rest operating systems are much smaller: $3.5 \%$ for RIM; $2.9 \%$ for Microsoft; $1.2 \%$ for Symbian; and $1.9 \%$ for the rest [9]. It shows that the market share for android platform is very large therefore the application developed based on this Operating system is likely to be used by many users in their mobile phones

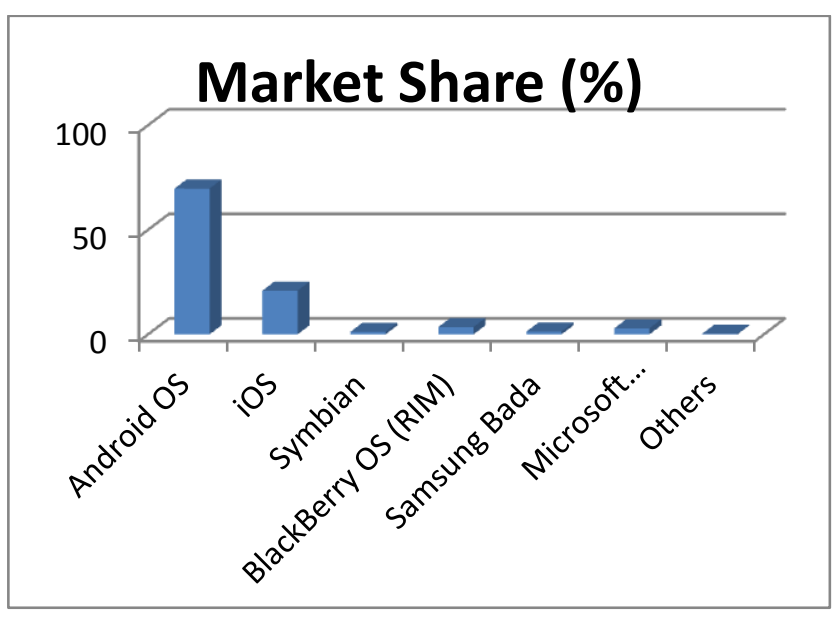

Figure 1: Operating Systems market share [9]

\section{REQUIREMENT ANALYSIS AND SPECIFICATIONS}

Requirements specify a set of features that the system must have. A functional requirement is a specification of a function that the system must support, whereas a nonfunctional requirement is a constraint on the operation of the system that is not related directly to a function of the system. The system abstraction in the figure below shows the 
complete setting of the system with four RFID catchment areas represented by four antennas.

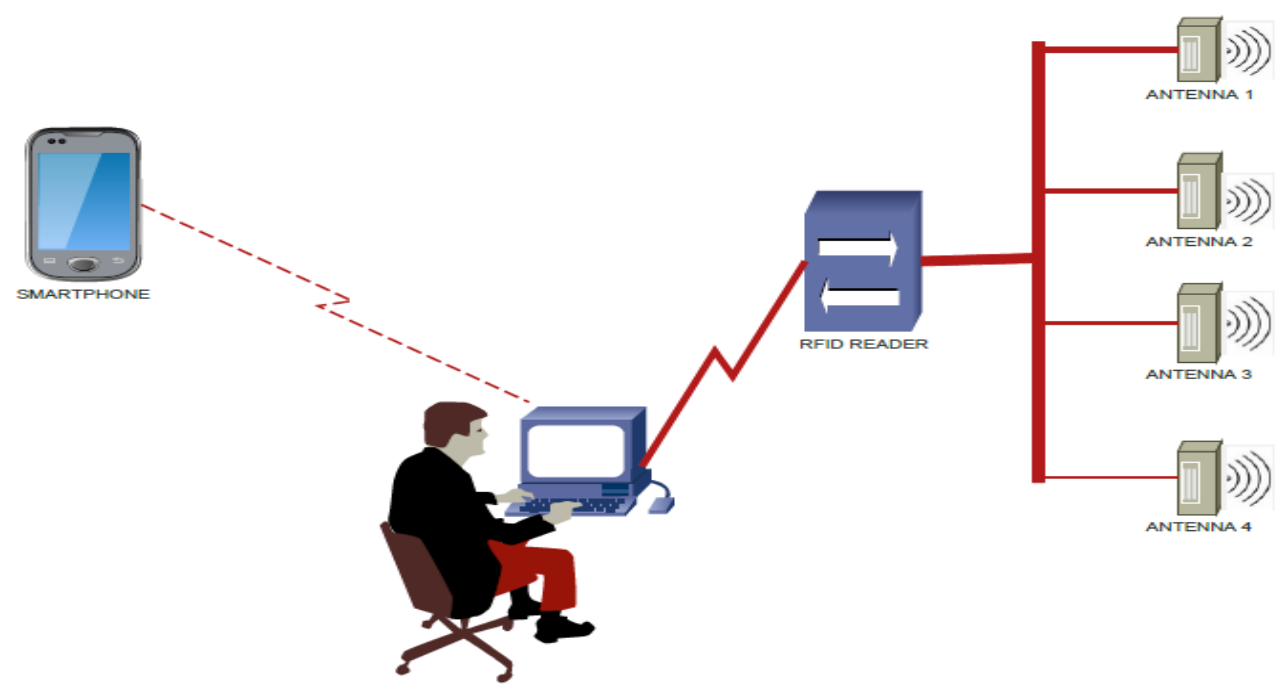

\subsection{Functional Requirements}

The attendance management system to be developed is expected to facilitate the process of recording attendance through mobile phone and RFID, viewing attendance for different interval of time and be able to send the attendance information to the parents/Guardians through mobile phone. The table 1 and 2 below shows the functional requirements for the Attendance management system and Mobile application respectively.

\section{Table 1: Attendance Management System Functional} Requirements

\begin{tabular}{|l|l|l|}
\hline ACTORS & REQUIREMENT & DESCRIPTION \\
\hline RFID Reader & Record Attendance & $\begin{array}{l}\text { RFID reader will be } \\
\text { recording the } \\
\text { attendance by } \\
\text { detecting the Tags } \\
\text { attached to student's } \\
\text { uniform. }\end{array}$ \\
\hline $\begin{array}{l}\text { Mobile } \\
\text { Application }\end{array}$ & $\begin{array}{l}\text { Record Attendance } \\
\text { Send Attendance } \\
\text { info }\end{array}$ & $\begin{array}{l}\text { Mobile application } \\
\text { acts as backup for } \\
\text { recording attendance } \\
\text { It will also be used to } \\
\text { send attendance } \\
\text { information to parents } \\
\text { or Guardians }\end{array}$ \\
\hline Class Teacher & $\begin{array}{l}\text { Login } \\
\text { View Attendance } \\
\text { Edit Student } \\
\text { Register Student }\end{array}$ & $\begin{array}{l}\text { Class teacher will } \\
\text { login into the system } \\
\text { and upon successful, } \\
\text { he/she will be able to } \\
\text { view attendance } \\
\text { information, Edit } \\
\text { student details and } \\
\text { Register new students. }\end{array}$ \\
\hline Head Master & $\begin{array}{l}\text { Login } \\
\text { View Attendance } \\
\text { Edit Student }\end{array}$ & $\begin{array}{l}\text { The Head Master will } \\
\text { login into the system, } \\
\text { view attendance, Edit }\end{array}$ \\
\hline
\end{tabular}

\begin{tabular}{|l|l|l|}
\hline & $\begin{array}{l}\text { Register Student } \\
\text { Delete Student }\end{array}$ & $\begin{array}{l}\text { students, Register } \\
\text { Students and Delete } \\
\text { Students. }\end{array}$ \\
\hline $\begin{array}{l}\text { Parent/Guardi } \\
\text { an }\end{array}$ & $\begin{array}{l}\text { Receive Attendance } \\
\text { info }\end{array}$ & $\begin{array}{l}\text { Parents or Guardians } \\
\text { will be receiving } \\
\text { attendance } \\
\text { information for their } \\
\text { kids in case of } \\
\text { truancy. }\end{array}$ \\
\hline
\end{tabular}

Table 2: Functional Requirements for Mobile Application

\begin{tabular}{|c|c|c|}
\hline ACTOR & REQUIREMENT & DESCRIPTION \\
\hline $\begin{array}{l}\text { Class } \\
\text { Teacher }\end{array}$ & $\begin{array}{l}\text { - Take attendance } \\
\text { - View attendance } \\
\text { - Upload attendance } \\
\text { - Login }\end{array}$ & $\begin{array}{l}\text { - The class } \\
\text { teacher/master is } \\
\text { required to be able to } \\
\text { take student } \\
\text { attendance and } \\
\text { upload to the back } \\
\text { end database in case } \\
\text { the RFID part is not } \\
\text { working or not } \\
\text { deployed. } \\
\text { - The class } \\
\text { teacher/master } \\
\text { should be able to } \\
\text { view student } \\
\text { attendance for } \\
\text { different interval of } \\
\text { time. }\end{array}$ \\
\hline $\begin{array}{l}\text { Head } \\
\text { Teacher/ } \\
\text { master }\end{array}$ & $\begin{array}{l}\text { - Edit student } \\
\text { - Register student } \\
\text { - Delete student } \\
\text { - View attendance } \\
\text { - Login }\end{array}$ & $\begin{array}{l}\text { - The head } \\
\text { Master/Teacher } \\
\text { monitors the } \\
\text { registered students } \\
\text { and their attendance. } \\
\text { She/he is also } \\
\text { responsible for } \\
\text { registering or deleting } \\
\text { student. }\end{array}$ \\
\hline
\end{tabular}




\subsection{Non-functional Requirements}

These are constraints on the operation of the system that are not related directly to a function of the system.

\begin{tabular}{|l|l|l|}
\hline S/N & REQUIREMENT & DESCRIPTION \\
\hline $\mathbf{1}$ & Operability & $\begin{array}{l}\diamond \text { The mobile application will } \\
\text { be developed under Android } \\
\text { platform. } \\
\end{array}$ \\
& & $\begin{array}{l}\diamond \text { The application will run on } \\
\text { Smartphone with android } \\
\text { OS 2.2 and above. }\end{array}$ \\
\hline $\mathbf{2}$ & Maintainability & $\begin{array}{l}\diamond \text { The application is } \\
\text { specifically for android } \\
\text { Smartphone }\end{array}$ \\
\hline
\end{tabular}

\begin{tabular}{|l|l|l|}
\hline 3 & Security & $\begin{array}{l}\diamond \text { The system shall provide } \\
\text { access to only registered } \\
\text { users. The authorized users } \\
\text { will login to the application }\end{array}$ \\
\hline $\mathbf{4}$ & Performance & $\begin{array}{l}\diamond \text { The application will process } \\
\text { attendance information as } \\
\text { faster as possible from the } \\
\text { moment of submission. }\end{array}$ \\
\hline
\end{tabular}

\section{SYSTEM DESIGN \\ 4.1 Use case Modelling}

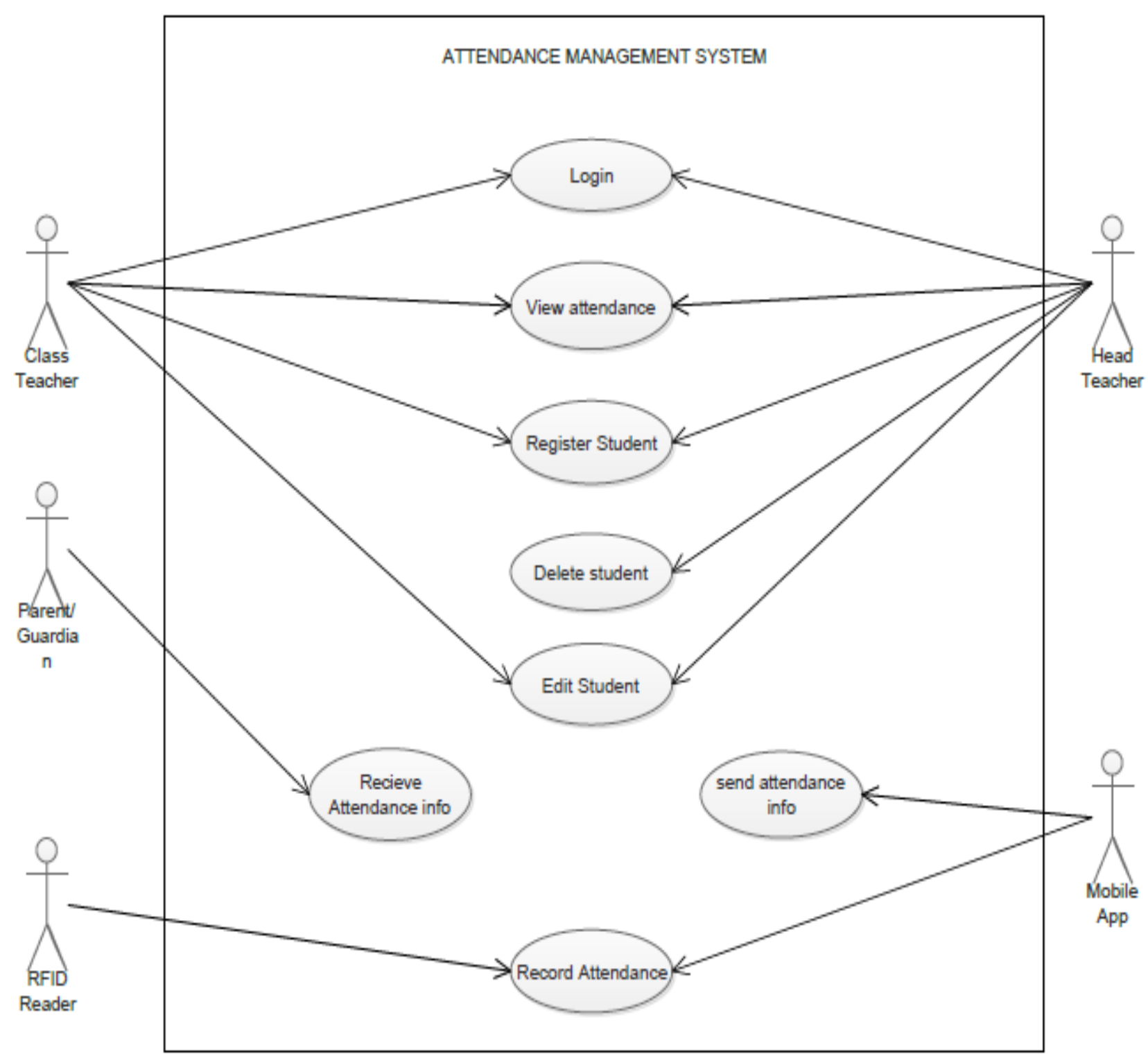




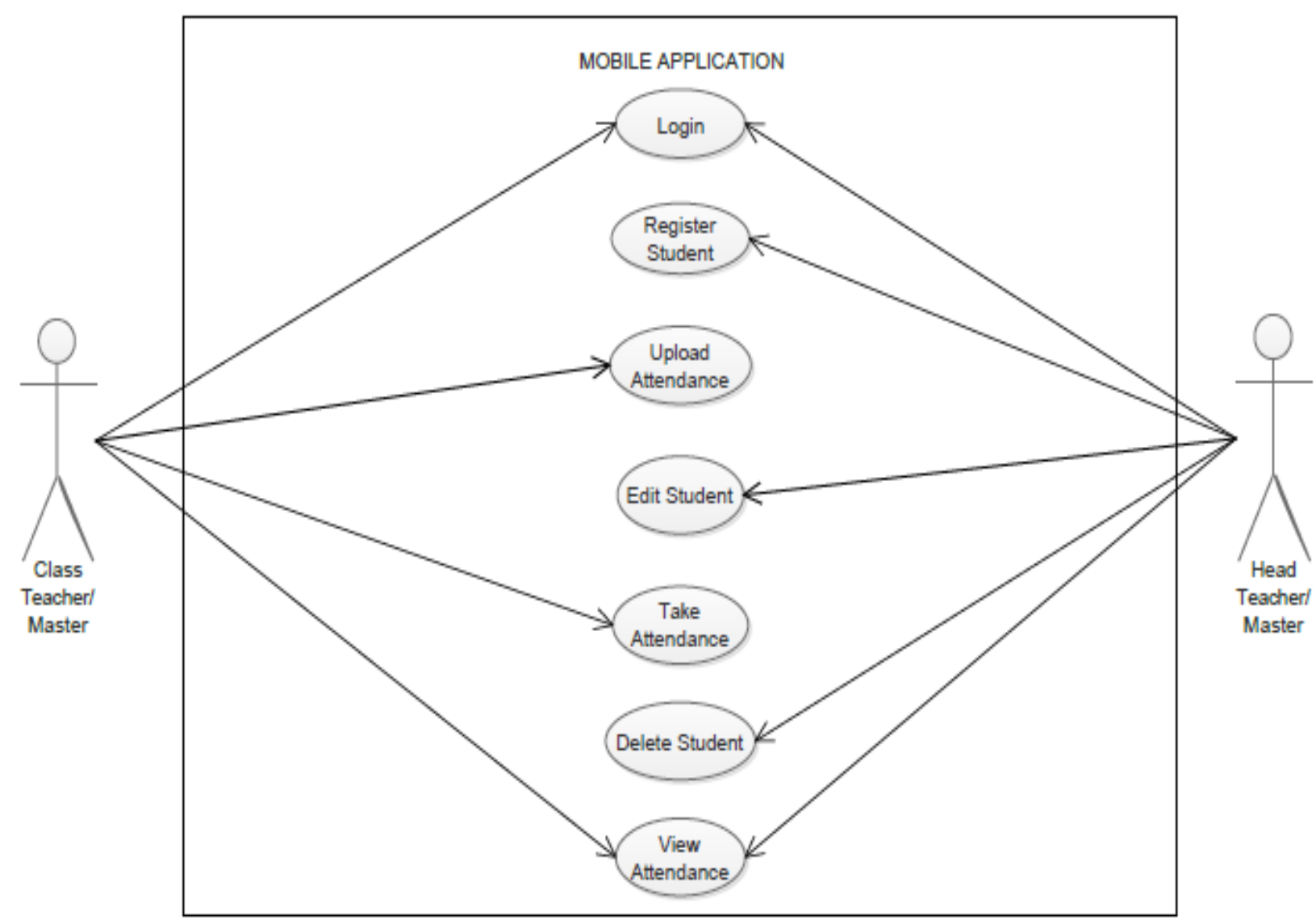

\subsection{Detailed Use Cases}

The tables below show the list of use cases with associated actors for attendance management system and the Mobile Application.

Table 3: Actors and associated use cases for Attendance Management System

\begin{tabular}{|c|c|}
\hline \multicolumn{2}{|c|}{ IVanagement system } \\
\hline PRIMARY ACTOR & USE CASE \\
\hline 1. RFID Reader & 1.1 Record Attendance \\
\hline 2. Mobile Application & $\begin{array}{l}\text { 2.1 Record Attendance } \\
\text { 2.2 Send Attendance Info }\end{array}$ \\
\hline $\begin{array}{ll}\text { 3. } & \text { Class } \\
& \text { Teacher/Master }\end{array}$ & $\begin{array}{l}\text { 3.1 Login } \\
\text { 3.2 View Attendance } \\
\text { 3.3 Edit Student } \\
\text { 3.4 Register Student }\end{array}$ \\
\hline $\begin{array}{ll}\text { 4. } & \text { Head } \\
& \text { Teacher/Master }\end{array}$ & $\begin{array}{l}\text { 4.1 Login } \\
\text { 4.2 View Attendance } \\
\text { 4.3 Edit Student } \\
\text { 4.4 Register Student } \\
\text { 4.5 Delete Student }\end{array}$ \\
\hline 5. Parent/Guardian & 5.1 Receive Attendance Info \\
\hline
\end{tabular}

Table 4: Actors and associated use cases for Mobile Application

\begin{tabular}{|c|c|}
\hline ACTORS & USE CASE \\
\hline $\begin{array}{ll}\text { 1. } & \text { Class } \\
& \text { Teacher/Master }\end{array}$ & $\begin{array}{ll}1.1 & \text { Login } \\
\text { 1.2 } & \text { Take attendance } \\
\text { 1.3 } & \text { View attendance } \\
1.4 & \text { Upload attendance }\end{array}$ \\
\hline $\begin{array}{ll}\text { 2. } & \text { Head } \\
& \text { Teacher/Master }\end{array}$ & $\begin{array}{ll}\text { 2.1 } & \text { Login } \\
2.2 & \text { Edit student } \\
2.3 & \text { Register student } \\
\text { 2.4 } & \text { Delete student } \\
\text { 2.4 } & \text { View attendance }\end{array}$ \\
\hline
\end{tabular}




\subsection{Entity Relationship Diagram}

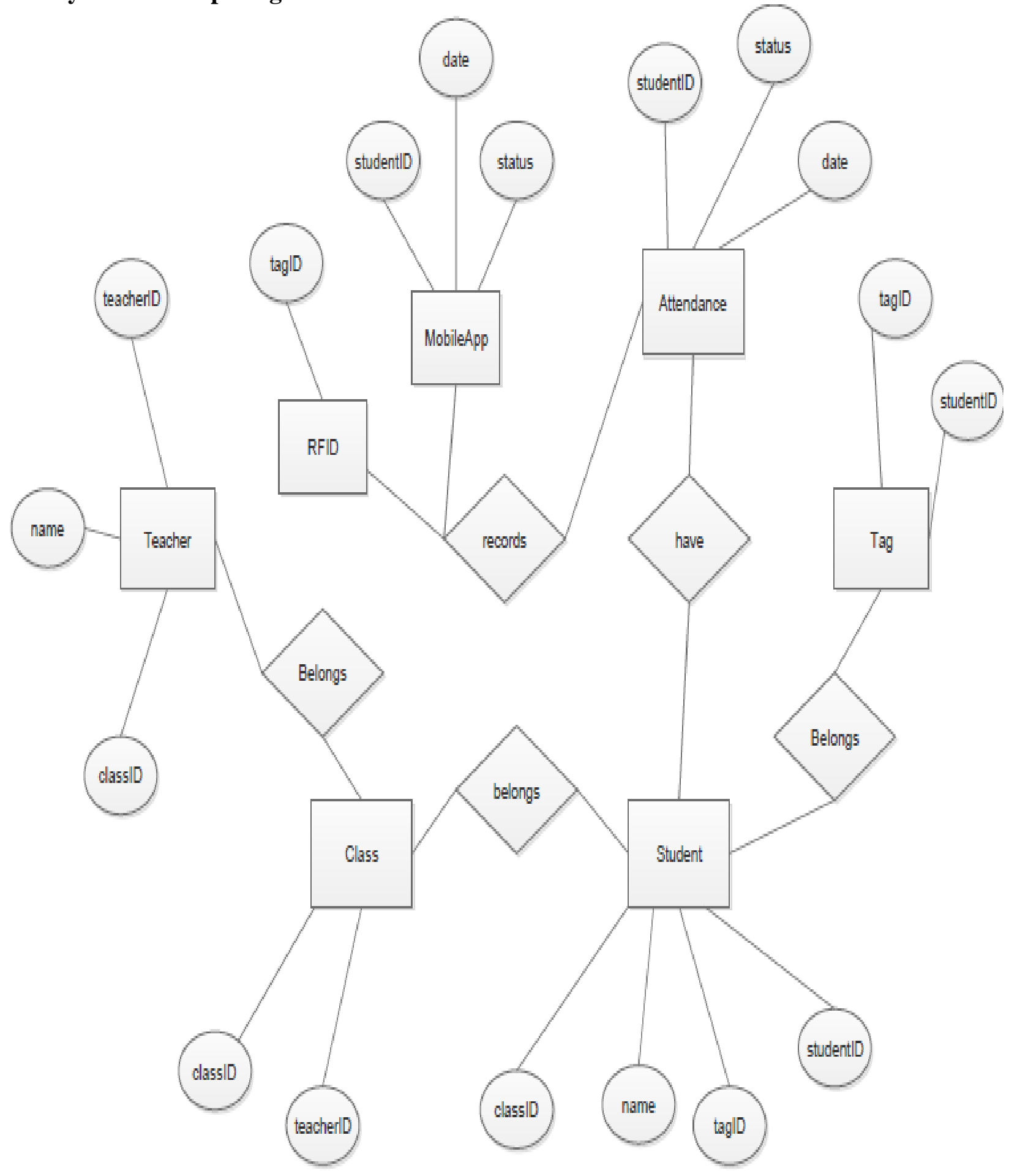

Figure 2: ERD of Attendance Management System 


\subsection{Class Diagram}

\section{RMAMS CLASS DIAGRAM}

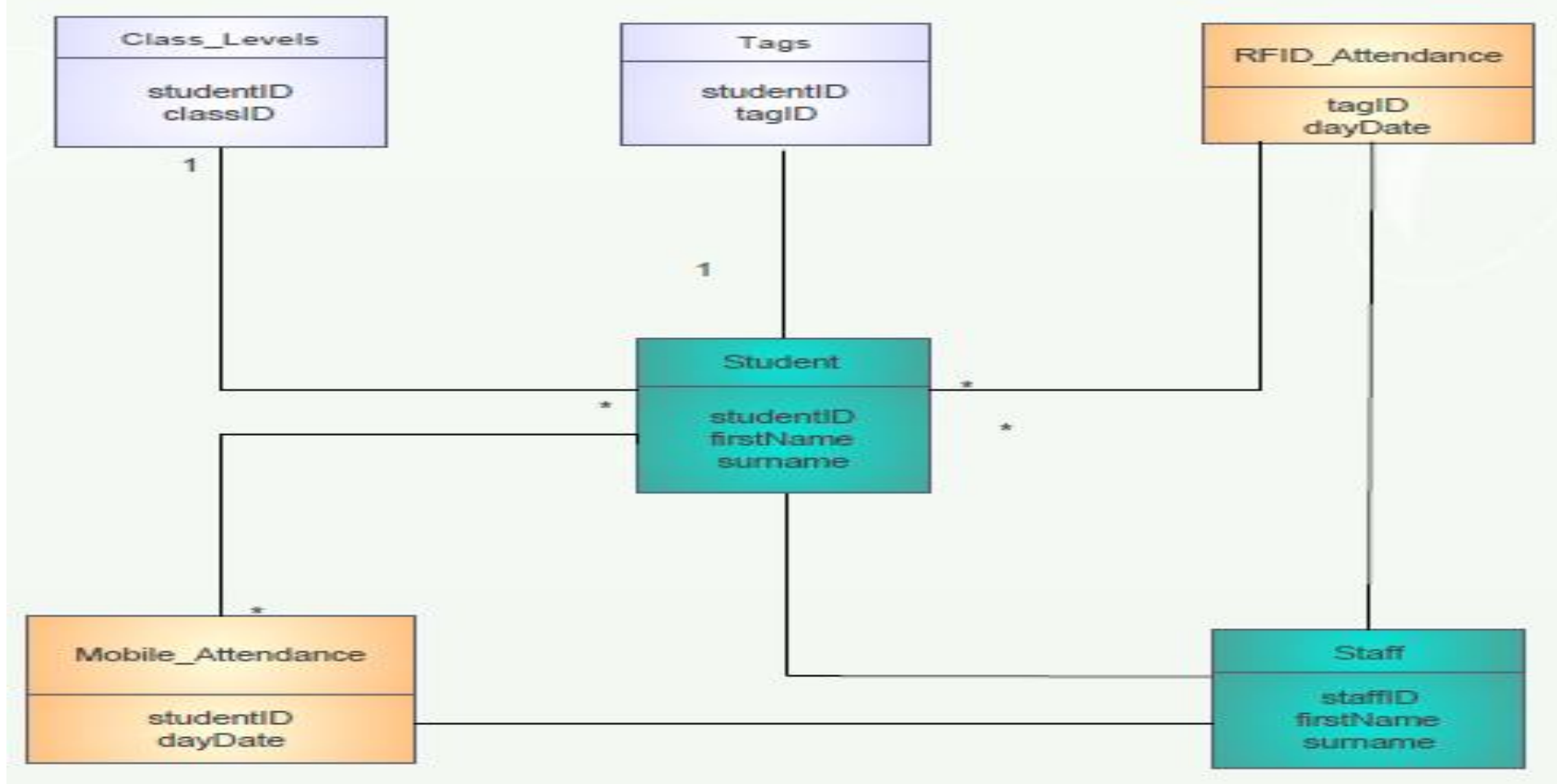

Figure 3: Class Diagram for Attendance Management System

\section{CONCLUSIONS}

The attendance management system tool whose specifications have been presented in this paper provides simple but efficient means of recording and communicating students' attendance information. We also see how requirement gathering and design are very critical in any software development to make sure that the project solves the right problem in a right approach. So long as many studies have shown that, mistakes at development stage often leads to project failure, care is needed when establishing the requirements in order to avoid any subsequent catastrophes. Results presented are a foundation for the design and development of a attendance management system which will also be improved through the feedback from the end users during testing and operation.

\section{REFERENCES}

[1] wikipedia. smartphone. Available: http://en.wikipedia.org/wiki/Smartphone

[2] A. I. Wasserman, "Software engineering issues for mobile application development," in Proceedings of the FSE/SDP workshop on Future of software engineering research, 2010, pp. 397-400.

[3] B. H. W. Alan Dennis, Roberta M. Roth., System Analysis and Design: VP \& PUBLISHER, 2012.

[4] Wikipedia. (14). Mobile app. Available: http://en.wikipedia.org/wiki/Mobile_app
[5] K. claus, "Title," unpublished|.

[6] I. C. S. S. E. S. Committee and I.-S. S. Board, "IEEE Recommended Practice for Software Requirements Specifications," 1998.

[7] S. Xanthopoulos and S. Xinogalos, "A comparative analysis of cross-platform development approaches for mobile applications," in Proceedings of the 6th Balkan Conference in Informatics, 2013, pp. 213-220.

[8] Egham. (2013, 16). Gartner Says Worldwide Mobile Phone Sales Declined 1.7 Percent in 2012. Available: http://www.gartner.com/newsroom/id/2335616

[9] O. Cinar, Android Apps with Eclipse: Apress, 2012.

[10] A. Rastogi and K. Gupta, "Student Attendance Through Mobile Devices," 2013.

[11] R. Meier, Professional Android 4 application development: John Wiley \& Sons, 2012.

[12] Wikipedia. (03). Radio Frequency Identification. Available: $\quad$ http://en.wikipedia.org/wiki/Radiofrequency_identification

[13] R. Want, "An introduction to RFID technology," Pervasive Computing, IEEE, vol. 5, pp. 25-33, 2006 